\title{
Cetacean bycatch in Indian Ocean tuna gillnet fisheries
}

\author{
R. Charles Anderson ${ }^{1, *}$, Miguel Herrera ${ }^{2}$, Anoukchika D. Ilangakoon ${ }^{3}$, K. M. Koya ${ }^{4}$, \\ M. Moazzam ${ }^{5}$, Putu L. Mustika ${ }^{6,7}$, Dipani N. Sutaria ${ }^{7}$ \\ ${ }^{1}$ Manta Marine, PO Box 2074, Malé, Republic of Maldives \\ ${ }^{2}$ OPAGAC, C/Ayala 54 2A, 28001 Madrid, Spain \\ ${ }^{3} 215$ Grandburg Place, Maharagama 10250, Sri Lanka \\ ${ }^{4}$ Central Marine Fisheries Research Institute, Kochi, Kerala 682018, India \\ ${ }^{5}$ WWF Pakistan, 46-K PECHS Block 6, Karachi 75400, Pakistan \\ ${ }^{6}$ Cetacean Sirenian Indonesia, Jl. Kalibaru Timur II/31, Kalibaru, Cilincing, North Jakarta 14110, Indonesia \\ ${ }^{7}$ College of Science and Technology, James Cook University, Townsville, Queensland 4811, Australia
}

\begin{abstract}
Pelagic gillnet (driftnet) fisheries account for some $34 \%$ of Indian Ocean tuna catches. We combined published results from 10 bycatch sampling programmes (1981-2016) in Australia, Sri Lanka, India and Pakistan to estimate bycatch rates for cetaceans across all Indian Ocean tuna gillnet fisheries. Estimated cetacean bycatch peaked at almost 100000 ind. $\mathrm{yr}^{-1}$ during 2004-2006, but has declined by over $15 \%$ since then, despite an increase in tuna gillnet fishing effort. These fisheries caught an estimated cumulative total of 4.1 million small cetaceans between 1950 and 2018. These bycatch estimates take little or no account of cetaceans caught by gillnet but not landed, of delayed mortality or sub-lethal impacts on cetaceans (especially whales) that escape from gillnets, of mortality associated with ghost nets, of harpoon catches made from gillnetters, or of mortality from other tuna fisheries. Total cetacean mortality from Indian Ocean tuna fisheries may therefore be substantially higher than estimated here. Declining cetacean bycatch rates suggest that such levels of mortality are not sustainable. Indeed, mean small cetacean abundance may currently be $13 \%$ of pre-fishery levels. None of these estimates are precise, but they do demonstrate the likely order of magnitude of the issue. Countries with the largest current gillnet catches of tuna, and thus the ones likely to have the largest cetacean bycatch are (in order): Iran, Indonesia, India, Sri Lanka, Pakistan, Oman, Yemen, UAE and Tanzania. These 9 countries together may account for roughly $96 \%$ of all cetacean bycatch from tuna gillnet fisheries across the Indian Ocean.
\end{abstract}

KEY WORDS: Bycatch · Gillnet · Driftnet · Dolphin

\section{INTRODUCTION}

Tropical tunas support some of the most valuable fisheries in the world. In the Indian Ocean in 2014, major tuna and tuna-like species were worth an estimated US $\$ 2.3$ billion ex-vessel and $\$ 7.4$ billion retail (Macfadyen 2016), from an estimated catch of some 1.7 Mt (IOTC 2019). Major tuna fishing gears in the Indian Ocean include purse seine, longline, pole-

*Corresponding author: charles.anderson11@btinternet.com and-line and handline. However, the single most important tuna fishing gear is pelagic gillnet (driftnet), which accounted for an average of $34 \%$ of total Indian Ocean tuna catch between 2012 and 2016.

A major issue for all gillnet fisheries is that they tend to entangle many bycatch species in addition to target fishes. In the case of Indian Ocean tuna gillnet fisheries (or more generally, large pelagic gillnet fisheries), non-tuna catch includes large numbers of restricted. Authors and original publication must be credited. 
sharks (although these are widely consumed in coastal countries, and the fins also have much value in Chinese markets, so they should perhaps be considered catch rather than bycatch), other finfish, turtles and cetaceans (Ardill et al. 2012, MRAG 2012, Aranda 2017, Garcia \& Herrera 2018). Some of these bycatch species are endangered, threatened and/or protected.

Cetacean bycatch in Indian Ocean tuna gillnet fisheries has been a concern for decades (Northridge 1991, Lal Mohan 1994, Perrin et al. 1994, Kiszka et al. 2008, Reeves et al. 2013, Anderson 2014, Temple et al. 2018) but has been poorly studied, in part due to a lack of political will to address the issue (Reeves et al. 2005, Ilangakoon 2006, Gillett 2011). This, in turn, reflects the regional reality that hundreds of thousands of relatively poor fishermen and their families rely on gillnet fisheries for their livelihoods and food.

Tuna gillnetting is carried out by many countries around the Indian Ocean, but there has been limited monitoring in just five of these: Australia, Sri Lanka, India, Pakistan and Tanzania. Australia has very limited pelagic gillnet fishing, but during the period from 1974-1985 Taiwanese drift netters operated in northwest Australian waters (Harwood et al. 1984, Harwood \& Hembree 1987, Hsu \& Liu 1990). An observer program estimated a total cetacean bycatch of some 14000 individuals during 1981-1985 (Harwood \& Hembree 1987). Elsewhere in the Indian Ocean, the Taiwanese high seas driftnet fishery targeting albacore may have taken 'in excess of 50000 cetaceans' per year (Cockcroft \& Krohn 1994) at its peak during the late 1980s. Taiwanese driftnet fishing was phased out from Australian waters during the 1980s, and ceased entirely in 1992 following the UN ban on high seas gillnetting.

Sri Lanka has a major pelagic gillnet fishery, with some $50 \%$ of the total fleet (i.e. over 2200 vessels in 2017) using gillnet or multi-gear sets, consisting of mostly gillnet and longline used during the same trip (Hewapathirana et al. 2018). In the early 1980s it became apparent that there was significant cetacean bycatch in this fishery (Alling 1983, 1985). This realization prompted several years of bycatch monitoring (e.g. Joseph \& Sideek 1985, Prematunga et al. 1985, Leatherwood \& Reeves 1989, Dayaratne \& de Silva 1991), with cetacean bycatch estimated to be in the order of 10000-40000 ind. $\mathrm{yr}^{-1}$. This information led to increased pressure on government agencies to reduce cetacean bycatch, with suggestions to ban gillnetting. The government responded with a national survey of small cetacean bycatch (Dayaratne \& Joseph 1993) which estimated a bycatch of 5181 dol- phins $\mathrm{yr}^{-1}$ during 1991-1992 for offshore gillnetters. This was apparently considered to be an acceptably low rate, and no further cetacean monitoring or research was conducted by the government. Limited subsequent research into cetacean bycatch was conducted independently (notably by Ilangakoon 1997, Ilangakoon et al. 2000a,b), but there have been no recent studies of cetacean bycatch. Current tuna catches are 2-3 times higher than in the 1980s and early 1990s, but national bans on the landing and selling of cetaceans are being enforced, with the result that cetaceans caught in gillnets are discarded at sea, kept on board for use as shark bait, or landed clandestinely; official records report near zero cetacean bycatch (Hewapathirana \& Gunawardane 2016, Hewapathirana et al. 2018).

India has an enormous fishing capacity with over 14000 motorised gillnet vessels in operation, although not all of those target tunas (Moreno \& Herrera 2013). The presence of cetacean bycatch among tuna and seerfish gillnet catches has long been recognized (e.g. Lal Mohan 1985, 1994, Kumarran 2012, Sathasivam 2004), but there appears to have been only one attempt to calculate national bycatch. That small study (Yousuf et al. 2009) roughly estimated cetacean bycatch by Indian gillnetters at 900010000 ind. $\mathrm{yr}^{-1}$ during 2004-2005. Subsequently, Koya et al. (2018) reported on a study that used skippers as observers on gillnetters off northwest India to record both tuna catch and cetacean bycatch.

Pakistan also has a large gillnetting fleet, with an estimated 820 pelagic gillnet vessels operating in 2017 (Khan 2018), including 200 small-scale inshore vessels (deploying gillnets of 3-5 km length) and 620 larger offshore vessels (5.5-17 km gillnets) (Khan 2018). There has been no official bycatch monitoring, but a major study of the gillnet fishery by the World Wildlife Fund (WWF) resulted in a series of reports on cetacean bycatch (e.g. Nawaz \& Moazzam 2014, Shahid et al. 2016). Those studies suggested that recent cetacean bycatch may have been in the order of 10000-12 000 ind. $\mathrm{yr}^{-1}$.

Tanzania has reported recent gillnet tuna catches in the order of $9000 \mathrm{t} \mathrm{yr}^{-1}$, but there is no estimate of the size of the gillnet fleet (Igulu \& El Kharousy 2013, Moreno \& Herrera 2013) nor any official reporting of cetacean bycatch (Igulu \& El Kharousy 2014). Nevertheless, the presence of significant cetacean bycatch has been recognized for more than 20 yr (Stensland et al. 1998). There has been some sampling, which concluded that the scale of bycatch might be a threat to local cetacean populations, but the data available did not allow estima- 
tion of the size of the national cetacean bycatch (Amir et al. 2002, 2005, 2012).

The top 2 Indian Ocean tuna gillnetting countries (Iran and Indonesia) have had no national monitoring of cetacean bycatch. Iran is by far the most important gillnet fishing country in the Indian Ocean, with a reported gillnet fleet of 3957 vessels in 2017 (Anon 2018), although that may be an underestimate. Iran accounts for some $38 \%$ of Indian Ocean tuna gillnet catches, but there have been just a few published mentions of cetacean bycatch (Braulik et al. 2009, 2010, Moazzam 2013). An official logbook scheme for Iranian gillnet skippers has reported zero cetacean bycatch (Shahifar 2012, 2017). A similar logbook system for fishing skippers in Sri Lanka, which also requires the recording of marine mammal bycatch, has reported such small numbers of cetaceans that the results are considered to be 'not satisfactory and unbelievable' (Hewapathirana et al. 2018, p. 12).

Indonesia accounts for some $13 \%$ of Indian Ocean tuna gillnet catch, and had an estimated gillnet fleet of 280600 vessels in 2011 (Ministry of Marine Affairs and Fisheries 2011), although much of that operates in FAO Fishing Area 71 (western and central Pacific) rather than FAO Fishing Area 57 (eastern Indian Ocean). There are indications of significant cetacean bycatch in Indonesia's gillnet tuna fishery (Kreb et al. 2013, Mustika et al. 2014), but no national estimate of bycatch.

The aims of the present paper were to review previous studies of cetacean bycatch in Indian Ocean tuna gillnet fisheries, identify those which might be used as indices of bycatch relative abundance and use those indices to make estimates of cetacean bycatch and bycatch trends from tuna gillnet fisheries for the entire tropical Indian Ocean. We attempted to produce conservative estimates, but we acknowledge that the data available are limited and these estimates are subject to much uncertainty.

\section{METHODS}

\subsection{Background}

There has been limited monitoring of most Indian Ocean tuna gillnet fisheries. Catch data for commercially important tuna and tuna-like species (compiled nationally) are available from 1950 (IOTC 2019). However, reliable fishing effort data are lacking for gillnet fleets. Although most countries have some measure of the size of their fleets and some have recorded numbers of days fished, with few local excep- tions (e.g. Shahid et al. 2015, Novianto et al. 2016), there is little information on gillnet sizes, materials (monofilament or multifilament), mesh sizes or hanging ratios (Moreno \& Herrera 2013, Aranda 2017). Tuna gillnets deployed in the Indian Ocean vary in length from barely $100 \mathrm{~m}$ to over $30 \mathrm{~km}$ in length, and less than $5 \mathrm{~m}$ to more than $20 \mathrm{~m}$ in depth, so this lack of information rules out the calculation of any meaningful measure of gillnet fishing effort. This, in turn, precludes the estimation of standard indices of cetacean abundance (i.e. bycatch per unit effort) for the relatively few cases in which cetacean bycatch data are available.

Therefore, we employed a different approach here, using cetacean bycatch per unit of tuna catch as a crude measure of cetacean relative abundance. Such an approach is common practice in bycatch investigations (e.g. Hall 1996, 1998, Romanov 2002, Amandè et al. 2012) and has also been applied to data-poor target species (e.g. Maunder \& Hoyle 2007, Punt et al. 2011). Among other things, this approach assumes that there is a direct relationship between tuna catch and cetacean bycatch, or more specifically, that the ratio of catchabilities remains constant in all situations. Uncertainties associated with this assumption are discussed below. We acknowledge that this approach is not ideal, and we encourage further investigation of the issue.

\subsection{Tuna catch data}

All tuna catch data are from the Indian Ocean Tuna Commission (IOTC) database (IOTC 2019). The only exception is for Pakistan: at the time of writing, catch data for 2015 and 2016 were not available from the IOTC database, which simply repeated catch records from 2014 (66 249 t). Here, we used catch data provided by Khan (2017): $77462 \mathrm{t}$ in 2015 and $97819 \mathrm{t}$ in 2016. Note that the IOTC database is dynamic and under constant review, so (mostly minor) discrepancies between analyses undertaken at different times are to be expected. For Sri Lanka, much of the recent tuna catch was reported as having been caught by 'multi-gear'. This indicates that vessels may have used gillnets and longlines during a single trip, and potentially also troll and other gears. In these cases, the catch by gillnet is recorded in the IOTC database under the subcategory 'GL' (with the subcategory 'LG' indicating catch by longline). Note that throughout this paper, we use the term 'tuna' to include not only tunas but also tuna-like species (seerfishes and billfishes), i.e. all the species on the IOTC's primary 
mandate. Because our study hinges on the use of tuna catch data, we use the term 'tuna gillnet' rather than the alternative 'large-pelagic gillnet'.

\subsection{Cetacean bycatch data}

We summarised bycatch monitoring studies that allowed estimation of national (or sub-national) cetacean bycatch (see Table 1); as far as we are aware, no other useable data are available. While large whales are also entangled in gillnets, they are rarely taken on board, so most catches are of small cetaceans. And although some small whales are landed, most landings are of dolphins. We use the terms small cetacean and dolphin interchangeably here.

In Sri Lanka, as landings of cetaceans from gillnetters increased during the 1980s, a market for dolphin meat developed (Leatherwood \& Reeves 1989, Ilangakoon 2002). As a result, gillnet fishermen from some ports started harpooning dolphins to sell ashore. Thus, national estimates of cetacean landings in later years included dolphins taken by harpoon as well as by gillnet. By the early 1990s, harpooned dolphins accounted for some $31 \%$ of all cetacean landings (Dayaratne \& Joseph 1993). We provide estimates of total dolphin bycatch and also dolphin bycatch by tuna gillnet, excluding catches by harpoon and by other gears (based on reported percentage of bycatch taken by harpoon in each study; see Table 1). Most Sri Lankan gillnet bycatch estimates during the 1980s were within the range of 700013500 small cetaceans $\mathrm{yr}^{-1}$. However, Alling (1985) estimated a cetacean bycatch of 42480 ind. $\mathrm{yr}^{-1}$ during 1982-1984. We consider that likely to have been an over-estimate, and did not use this data point in our analysis. Leatherwood \& Reeves (1989) estimated cetacean bycatch to be within the range of 26332-49 863 ind. $\mathrm{yr}^{-1}$ during 1984-1986; that was subsequently corrected to 8042-11821 by Leatherwood (1994). Dayaratne \& Joseph (1993) estimated the annual small cetacean bycatch from the offshore gillnet fishery (including harpoon catches) to have been 5181 individuals during 1991-1992. Mean tuna catch during that period was $26014 \mathrm{t} \mathrm{yr}^{-1}$. However, tuna catch by offshore gillnetters was reported to be about 20000 t y$^{-1}$ (Dayaratne \& Joseph 1993); we used this figure to estimate bycatch per unit tuna catch. The study of Dayaratne \& Joseph (1993) appears to be the most comprehensive cetacean bycatch study yet undertaken in the Indian Ocean. However, their report does not give sufficient infor- mation to check all calculations. The study employed 7 samplers to cover 14 major landing sites; those samplers worked an average of $18.4 \mathrm{~d} \mathrm{mo}^{-1}$. Assuming a possible 24 landing days $\mathrm{mo}^{-1}$ (A. Ilangakoon pers. obs.), the samplers may have covered approximately $38 \%$ of landings. Given that 2791 landed cetaceans were recorded, it is possible that the total cetacean landings may have been over 7000, rather than the total of 5181 reported by Dayaratne \& Joseph (1993). In addition, the number of cetaceans caught but not landed is unknown. We also note that the study of Dayaratne \& Joseph (1993, p. ii) was commissioned specifically to counter the 'very high estimates of dolphin landings ... [that] had been made in the past and were causing much concern in the island.' Nevertheless, we used their apparently conservative cetacean bycatch estimate of 5181 ind. $\mathrm{yr}^{-1}$ here.

In India, Yousuf et al. (2009) estimated the bycatch of cetaceans taken in gillnets around India in 2004-2005 to be about 9000-10 000 ind. $\mathrm{yr}^{-1}$. We note that this estimate included bycatch from all gillnet fisheries, although the authors did note that 'the maximum number of dolphin entanglements [were] encountered in the pelagic fishery for yellowfin tuna ... and seerfish' Yousuf et al. (2009, p. 2). With that in mind, we used the lower end of their estimated range (i.e. 9000 small cetaceans $\mathrm{yr}^{-1}$ ). We also note that the bycatch estimate of Yousuf et al. (2009) was based on a very small sample (just 44 dolphins from 3 landing sites) and so may not be particularly accurate. In addition, as the authors themselves noted, their landing site sampling was limited to just $3 \mathrm{~h}$ per sampling day, and likely underestimated total cetacean landings. Koya et al. (2018) reported a bycatch of 30 dolphins from skippers' log sheet records of 567 gillnet fishing operations conducted off the northwest coast of India during 2011-2016. Tuna catch was also reported, but in numbers. We estimate that the catch weight of tuna and tuna-like species was $148.8 \mathrm{t}$ (see Table S1 in the Supplement at www.int-res.com/ articles/suppl/n041p039_supp.pdf), and thus that the estimated bycatch rate for this fishery was 202 small cetaceans per $1000 \mathrm{t}$ tuna. For the whole of India, average annual tuna gillnet catch during 2011-2016 was 71550 t (IOTC 2019), which suggests that annual average bycatch was of the order of 14400 ind. $\mathrm{yr}^{-1}$.

In Pakistan, bycatch sampling under a WWF project produced estimates of annual cetacean bycatch of about 12000 ind. $\mathrm{yr}^{-1}$ in 2013 and 10150 ind. $\mathrm{yr}^{-1}$ in 2014 (Nawaz \& Moazzam 2014, Shahid et al. 2016). The 2013 estimate was based on sampling by 4 observers on 4 gillnetters (out of a fleet of 560 vessels) who completed an average of $270 \mathrm{~d}$ sampling 
and recorded a total cetacean bycatch of 86 dolphins (M. Moazzam unpubl. data). For 2014, there were again 4 observers on 4 gillnetters (out of a fleet of 610 vessels) who completed an average of $260 \mathrm{~d}$ sampling, and recorded a total cetacean bycatch of 67 dolphins (M. Moazzam unpubl. data). Shahid et al. (2016) also reported a cetacean bycatch of 17200 individuals in 2015, citing Nawaz \& Moazzam (2014); however, there was no bycatch estimate for 2015, and that report was in error (M. Moazzam pers. obs.).

\subsection{Cetacean bycatch per unit tuna catch}

In addition to cetacean bycatch estimates, we also list annual tuna catches for the relevant study periods (see Table 1). In most cases these are national tuna catches, but there are 3 exceptions. For Australia (1981-1985), $6227 \mathrm{t}$ is the estimated mean annual tuna catch for the Taiwanese gillnet fishery (Harwood \& Hembree 1987), not the whole country. For Sri Lanka (1991-1992), the mean annual tuna catch was $26014 \mathrm{t}$, but the estimated annual catch for the offshore gillnet fishery studied by Dayaratne \& Joseph (1993) was 20000 t. For India (2011-2016), cetacean catch rate was calculated directly from sample data, namely 30 dolphins in $148.8 \mathrm{t}$ of tuna (Koya et al. 2018; also see the Supplement). From each of the 10 sampling programmes, we calculated small cetacean bycatch per $1000 \mathrm{t}$ tuna catch (see Table 1). These 10 estimates are plotted by year (see Fig. 1); the curve fitted to the data points is an empirical best fit.

\subsection{Cumulative bycatch}

IOTC maintains tuna catch records from 1950, and using those data it is possible to make an estimate of the total cetacean bycatch in the Indian Ocean gillnet fisheries since that time. However, our estimates of cetacean bycatch rates only extend back to the early 1980s. It is likely that bycatch rates may have been higher prior to that. The bycatch data from Sri Lanka and Australia suggest a mean bycatch rate of about 526 cetaceans per $1000 \mathrm{t}$ of tuna (see Table 1 ) in the 1980s and a mean bycatch in excess of 600 cetaceans per $1000 \mathrm{t}$ of tuna prior to the late 1970s (see Fig. 1). As a first approximation, we assumed a conservative mean bycatch rate of 600 cetaceans per $1000 t$ of tuna prior to 1978.

During the 1950s, and before, cotton gillnets were in use throughout the region. These are presumed to have had lower cetacean bycatch rates, because dolphins could sometimes break free and escape. The widespread adoption of stronger synthetic fibre gillnets in the 1960s would have increased cetacean bycatch rates. In India, synthetic fibre gillnets were first introduced from the late 1950s (Radhalekshmy \& Nayar 1973), and their use became widespread once local production started in 1966, although very small numbers of cotton gillnets were still in use in the 1990s (Sathasiva Lingom 2002). In Sri Lanka, synthetic fibre gillnets were introduced from 1962 (Gunaratna 1989). As a first approximation, we assumed that synthetic fibre gillnets were first introduced in the region in 1958, had completely replaced cotton nets within $15 \mathrm{yr}$, and had twice the cetacean bycatch of cotton gillnets.

With these assumptions, we estimated cetacean bycatch rates for every year since 1950 as shown below; from these catch rates, and known tuna catch records, cumulative cetacean bycatch since 1950 was calculated. Note that cumulative tuna catch from 1950-1977 was just $9 \%$ of the total from 1950-2018, so even quite large changes to these assumptions would have relatively minor impacts on cetacean bycatch estimates.

1950-1957: 300 small cetaceans per 1000 t tuna

1958-1971: linear change to:

1972-1977: 600 small cetaceans per $1000 \mathrm{t}$ tuna

1978-2016: empirical equation (see Fig. 1).

\subsection{Relative abundance}

We estimated cetacean bycatch rates relative to tuna catch. However, the tuna stocks against which these cetacean bycatch estimates were made are themselves heavily exploited. The IOTC estimated stock status for several of the tuna and tuna-like species exploited by Indian Ocean gillnet fisheries (IOTC 2017a). These estimates are summarised in Table S2.

\subsection{Uncertainty and bias}

This study was based on the premise that cetacean bycatch is related to tuna catch in Indian Ocean tuna gillnet fisheries. It used estimates of cetacean bycatch from particular countries and years, together with estimates of national (or sub-national) tuna catch to estimate cetacean bycatch per $1000 \mathrm{t}$ of tuna catch, and then this was scaled up to make estimates for total Indian Ocean cetacean bycatch. There are 
several non-trivial sources of uncertainty with this approach.

Cetacean bycatch numbers: The only study which calculated a range of values for cetacean bycatch was that of Leatherwood (1994, itself based on an earlier study by Leatherwood \& Reeves 1989). Sri Lankan annual cetacean bycatch in 1984-1985 was estimated to be within the range of 8042-11 821 ind., i.e. a mean of $9932 \pm 19 \%$. There is also likely to be bias in cetacean bycatch estimation: there are many reasons why bycatch should be under-reported, few why they should be over-reported. For example, with his bycatch estimate for Sri Lanka, Leatherwood (1994) excluded cetaceans that were killed in gillnets but not landed or landed but not counted, and also used a low value of bycatch per vessel. Also in Sri Lanka, Dayaratne \& Joseph (1993) did not account for cetaceans killed but not landed, and appear to have made no allowance for cetaceans landed but not tallied at monitored sites. We have no empirical data to estimate the magnitude of this bias. However, our aim here was to produce a conservative estimate of cetacean bycatch. Therefore, we ignored this likely underestimation in our calculations and assumed an uncertainty of $\pm 20 \%$ for cetacean bycatch data

Tuna catch data: There is much uncertainty in Indian Ocean tuna gillnet catch records, with data quality considered to be of poor to fair quality, depending on the country and time period (Fiorellato et al. 2018) and uncertainty in many cases being in the order of $\pm 10-20 \%$. It is also believed that there are biases in many national tuna reports. Historically, many countries' tuna catches have been under-reported. More recently, it appears that some coastal countries are over-reporting tuna catches, for reasons both financial (to take advantage of state subsidies) and political (to appear to meet national development targets or to develop historical catch series in order to improve future fishing allocation opportunities). The scale of such biases are unknown, but are likely to be of the order of $10 \%$ in many cases and greater in some (M. Herrera [former Statistical Officer, IOTC] pers. obs). As a rough estimate, we assumed a mean uncertainty of $\pm 20 \%$ for tuna gillnet catch data.

Cetacean-tuna relationship: Our assumption of a direct relationship between tuna catch and cetacean bycatch was based on 3 assertions. Firstly, that greater gillnet fishing effort will produce both more tuna catch and more bycatch. Secondly, that in more productive waters there will be more large consumers, including both tunas and cetaceans. As an example, from the Indian Ocean purse seine fishery, it is known that both tunas and whales are particularly abundant in the waters east of Seychelles during the first quarter of the year, and in the Mozambique Channel during the second quarter (Robineau 1991, Escalle et al. 2015). However, we know of no similar information for the Indian Ocean tuna gillnet fishery. Thirdly, we assumed that the ratio of tuna catchability to dolphin catchability was constant (cf. Carruthers 2018) between different gillnet fleets operating in different areas and at different times. The programmes (see Table 1) sampled 4 different gillnet fishing fleets, presumably operating with different net configurations, in different areas, and in some cases at different times. The fact that similar cetacean bycatch rates were estimated for Australia and Sri Lanka during the period 1981-1986 and also for Pakistan and India during 2013-2016 (see Fig. 1) does suggest that there is some merit to the assumption that comparisons can be made between fleets and between fishing areas. However, these data shed no light on our assumption that the ratio of catchabilities remained more or less constant over the $35 \mathrm{yr}$ spanned by the studies reviewed here. And there are reasons why this assumption might not be valid (e.g. Wade et al. 2012, Vertpre et al. 2013). Nevertheless, in the absence of evidence to the contrary, we assumed that there was a direct relationship between tuna catch and dolphin bycatch in Indian Ocean gillnet fisheries. For this working assumption, as a first rough estimate we assigned an arbitrary uncertainty of $\pm 10 \%$.

These uncertainties are independent and should be additive. Thus, the total measure of uncertainty associated with individual estimates of cetacean bycatch per unit of tuna catch may be in the order of $\pm 40 \%$, while uncertainty associated with our estimates of national and total Indian Ocean cetacean bycatch may be in the order of $\pm 50 \%$. We used these ranges throughout, but stress that they are not statistically rigorous confidence intervals, and that they should not be taken to imply strict bounds on our estimates. Rather, they are intended only to give an idea of the possible scale of uncertainty. We encourage further more rigorous analysis and modelling to refine these estimates and uncertainties.

A further implicit assumption of this study is that national estimates of cetacean bycatch rates are representative of the entire Indian Ocean. This is almost certainly not correct. The Indian Ocean is oceanographically heterogeneous (Longhurst 1998, Spalding et al. 2007, 2012), and several cetacean species show population structure within the ocean, for example blue whales Balaenoptera musculus (Branch et al. 2007, Samaran et al. 2013), Indo-Pacific bottlenose dolphins Tursiops aduncus (Gray et al. 
2018), humpback dolphins Sousa spp. (Mendez et al. 2011, Jefferson \& Rosenbaum 2014) and common dolphins Delphinus spp. (Jefferson \& Waerebeek 2002, Perrin 2009). Consequently, areas with high cetacean bycatch (which are precisely the areas where bycatch sampling has been conducted) may show depletion of local cetacean stocks, which does not reflect their status in the wider Indian Ocean. As a result of this potential source of bias, our study may overestimate the rate of decline in ocean-wide cetacean abundance, although this in turn may contribute to an underestimation of cetacean bycatch, including cumulative cetacean removals. Modelling of bycatch and cetacean population trajectories may provide additional insights.

\section{RESULTS}

Estimates of cetacean bycatch per $1000 \mathrm{t}$ of tuna catch are shown in Table 1 and Fig. 1. It appears that the cetacean bycatch rate has declined dramatically since the 1980s. From the relationships between cetacean bycatch and tuna catch shown in Fig. 1 and outlined above, as well as annual tuna catch data, the estimated cetacean bycatch for each year from 1950-2016 was calculated, and is shown in Fig. 2. Indian Ocean cetacean bycatch is esti-

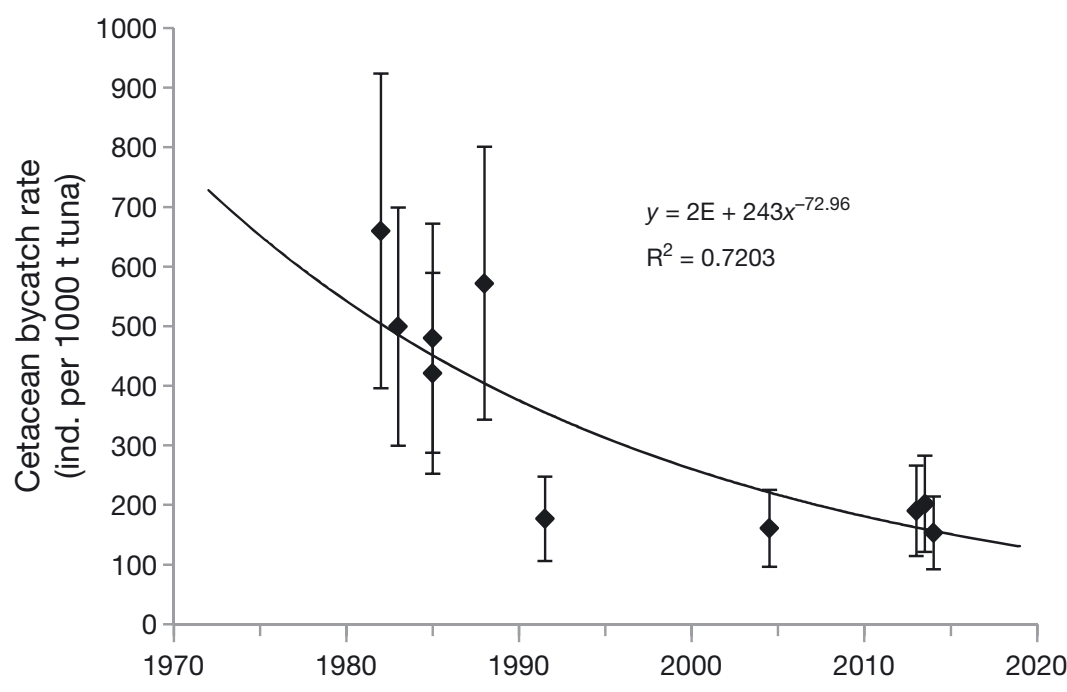

Fig. 1. Estimates of small cetacean bycatch rates (mean $\pm 40 \%$ ) in Indian Ocean tuna gillnet fisheries, 1982-2016

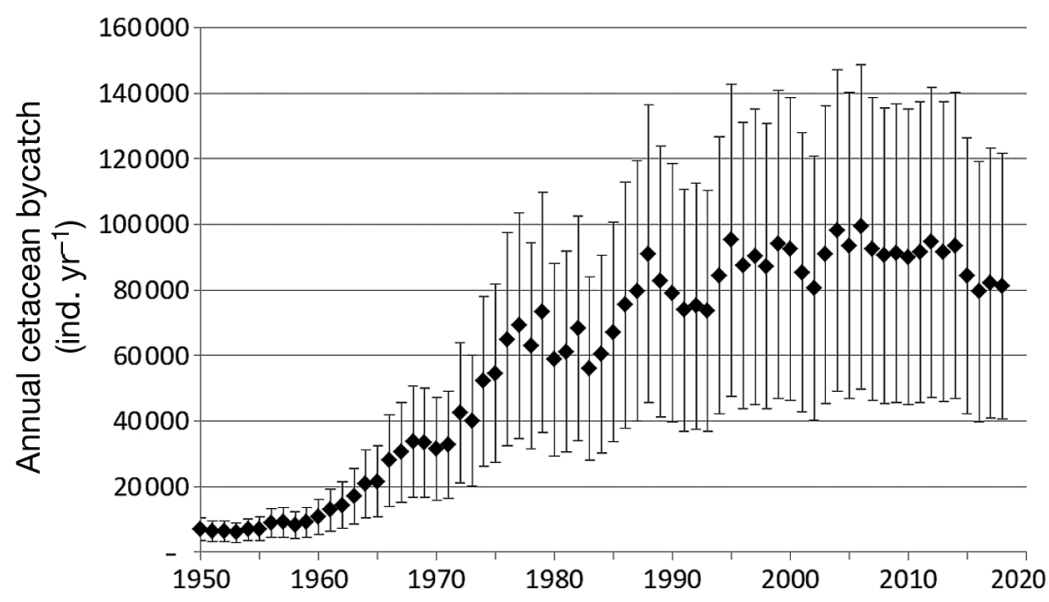

Fig. 2. Estimated annual small cetacean bycatch (mean $\pm 50 \%$ ) in Indian Ocean tuna gillnet fisheries for each year, 1950-2018

Table 1. Estimates of dolphin bycatch (number of individuals) from different localities by port sampling and observer programmes in the Indian Ocean (see Section 2.3 for comments). NA: not available

\begin{tabular}{|lcccccl}
\hline Location & Date & $\begin{array}{c}\text { Annual dolphin } \\
\text { bycatch (gillnet } \\
\text { and others) }\end{array}$ & $\begin{array}{c}\text { Annual dolphin } \\
\text { gillnet bycatch }\end{array}$ & $\begin{array}{c}\text { Annual tuna } \\
\text { gillnet } \\
\text { catch (t) }\end{array}$ & $\begin{array}{c}\text { Dolphins per } \\
\text { 1000 t tuna } \\
\text { (gillnet) }\end{array}$ & Bycatch data source \\
\hline Sri Lanka & 1982 & NA & 13500 & 20463 & 660 & Alling (1983) \\
Australia & $1981-1985$ & NA & 3109 & 6227 & 499 & Harwood \& Hembree (1987) \\
Sri Lanka & 1985 & 9129 & 8216 & 17103 & 480 & Joseph \& Sideek (1985) \\
Sri Lanka & $1984-1986$ & $8042-11821$ & 7237 & 17192 & 421 & Leatherwood (1994) \\
Sri Lanka & 1988 & 12950 & 11655 & 20389 & 572 & Dayaratne \& de Silva (1991) \\
Sri Lanka & $1991-1992$ & 5181 & 3549 & 20000 & 177 & Dayaratne \& Joseph (1993) \\
India & $2004-2005$ & $9000-10000$ & 9000 & 55869 & 161 & Yousuf et al. (2009) \\
India & $2011-2016$ & NA & 14453 & 71550 & 202 & Koya et al. (2018) \\
Pakistan & 2013 & NA & 12000 & 63104 & 190 & Nawaz \& Moazzam (2014) \\
Pakistan & 2014 & NA & 10150 & 66249 & 153 & Shahid et al. (2016) \\
\hline
\end{tabular}


mated to have peaked at almost 100000 cetaceans $\mathrm{yr}^{-1}$ (range: 50 000-150 000) during 2004-2006, but has declined since then, and may currently be in the order of 80000 cetaceans $\mathrm{yr}^{-1}$ (range 40000 $120000)$. The cumulative cetacean bycatch for all Indian Ocean tuna gillnet fisheries during the period 1950-2016 is estimated to be 3.9 million (Fig. 3). Extrapolating to 2018, the cumulative cetacean bycatch is estimated to be 4.1 million ind. (range: 2.0-6.2 million).

\section{DISCUSSION}

\subsection{Cetacean bycatch}

The bycatch in Indian Ocean tuna gillnet fisheries is estimated here to have increased to a peak of almost 100000 small cetaceans $\mathrm{yr}^{-1}$ during 2004-2006, and decreased to just over 80000 ind. $\mathrm{yr}^{-1}$ currently. These estimates do not include cetaceans that were caught by gillnet but discarded at sea, used as bait and not landed, escaped from capture but subsequently died or suffered significant sub-lethal impacts, caught in ghost nets or landed but not recorded.

This scale of cetacean bycatch is compatible with that reported by 2 previous studies. Anderson (2014) reported on cetacean bycatch from tuna gillnet fisheries in the western and central Indian Ocean (i.e. excluding the eastern Indian Ocean) and estimated that something in the order of 60000 cetaceans might be taken annually as bycatch in that region's tuna gillnet fisheries. Garcia \& Herrera (2018) estimated a total cetacean bycatch of 172000 small cetaceans

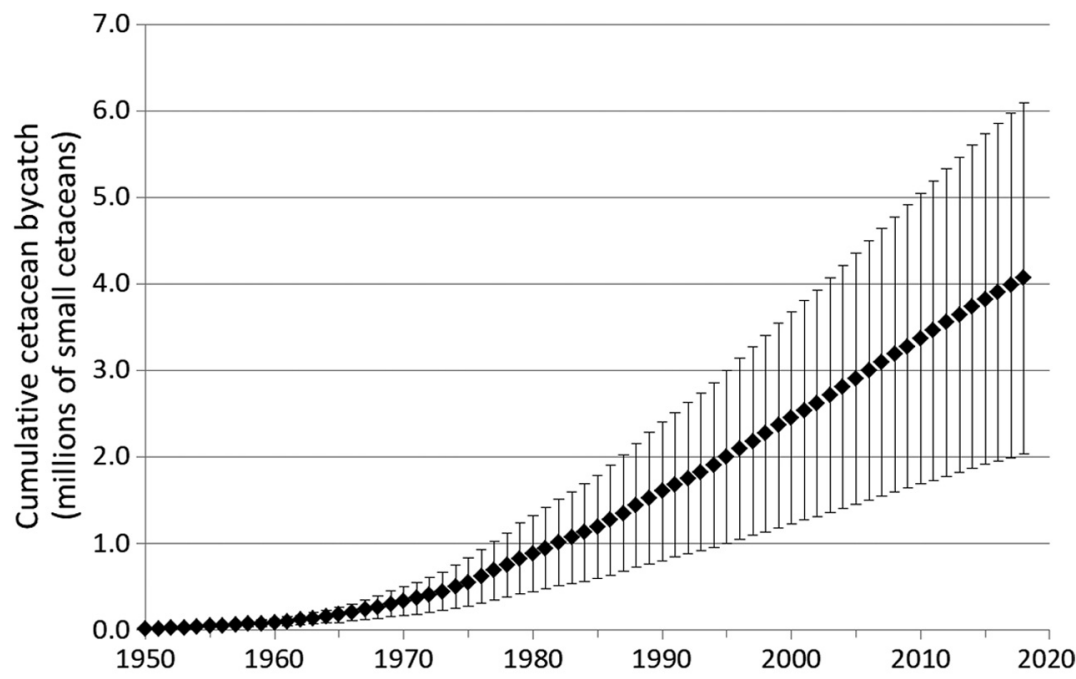

Fig. 3. Cumulative bycatch of cetaceans from Indian Ocean tuna gillnet fisheries, 1950-2018 (estimated mean annual values $\pm 50 \%$ ) from all Indian Ocean tuna gillnet fisheries (by substituting published bycatch rates from Pakistan and Sri Lanka for all countries, without taking account of possible recent declines in bycatch rates).

Indicative estimates of annual cetacean bycatch by country are given in Table 2. Iran, with $38 \%$ of the total gillnet tuna catch, has by far the largest cetacean bycatch, estimated at about 30000 small cetaceans $\mathrm{yr}^{-1}$. India, Indonesia, Sri Lanka and Pakistan all have estimated cetacean bycatch from their gillnet tuna fisheries in the approximate range of 8000-10 000 ind. $\mathrm{yr}^{-1}$. Other countries with estimated cetacean bycatch in excess of 1000 ind. $\mathrm{yr}^{-1}$ are Oman, Yemen, UAE and Tanzania. These 9 countries account for some $96 \%$ of the total Indian Ocean tuna gillnet catch, and hence also $96 \%$ of the estimated cetacean bycatch.

We estimated cumulative cetacean bycatch by Indian Ocean tuna gillnet fisheries during 1950-2018 to have been in the order of 4.1 million cetaceans (range: 2.0-6.2 million). As such a wide range suggests, this estimate is subject to many uncertainties. Nevertheless, this level of cetacean mortality is of the same order of magnitude as the cetacean take from 2 other major fisheries: commercial whaling and the eastern tropical Pacific purse seine fishery, both of which have received far more attention from scientists, conservationists and resource managers. Commercial whaling is estimated to have taken some 2.9 million whales during the 20th century (Rocha et al. 2014). The eastern Pacific tuna purse seine fishery uses the association of dolphins with yellowfin tuna Thunnus albacares to locate and catch the tuna. Cumulative bycatch has been estimated to be in excess of 6 million small cetaceans (Gerrodette 2009), although that might be an overestimate because there are considerable uncertainties in bycatch estimates for the earliest years of the fishery (Hall \& Roman 2013, p. 191). That the Indian Ocean gillnet fishery and the eastern Pacific purse seine fishery are of a similar scale is not a new insight: Jayaprakash et al. (1995, p. 132) noted that dolphin mortality in the former was 'as alarming as in the Eastern Pacific region.' The International Whaling Commission (IWC) introduced a moratorium on commercial whaling in 1986, and several effective conservation measures were introduced in the eastern Pacific purse seine fishery, mainly during the 1980s 
Table 2. Recent gillnet catches of tuna and tuna-like species (annual average for 2012-2016) by county, with indicative estimates of annual cetacean bycatch by country, assuming a total Indian Ocean-wide gillnet bycatch of 80000 individuals (which is the approximate estimated current cetacean bycatch)

\begin{tabular}{|c|c|c|c|c|c|c|}
\hline Rank & Country & $\begin{array}{l}\text { Annual tuna gillnet } \\
\text { catch 2012-2016 (t) }\end{array}$ & $\begin{array}{l}\% \text { of gillnet } \\
\text { catch }\end{array}$ & $\begin{array}{c}\sum \% \text { of } \\
\text { gillnet catch }\end{array}$ & \multicolumn{2}{|c|}{$\begin{array}{l}\text { Indicative annual cetacean } \\
\text { bycatch: mean }( \pm 50 \%)\end{array}$} \\
\hline 1 & Iran & 214262 & 37.9 & 37.9 & 30302 & $(15151-45453)$ \\
\hline 2 & Indonesia & 75689 & 13.4 & 51.3 & 10704 & $(5352-16057)$ \\
\hline 3 & India & 72048 & 12.7 & 64.0 & 10189 & (5095-15284) \\
\hline 4 & Sri Lanka & 64857 & 11.5 & 75.5 & 9172 & (4586-13759) \\
\hline 5 & Pakistan & 58781 & 10.4 & 85.9 & 8313 & $(4147-12470)$ \\
\hline 6 & Oman & 21090 & 3.7 & 89.6 & 2983 & $(1491-4474)$ \\
\hline 7 & Yemen & 15201 & 2.7 & 92.3 & 2150 & $(1075-3225)$ \\
\hline 8 & UAE & 14503 & 2.6 & 94.8 & 2051 & $(1026-3077)$ \\
\hline 9 & Tanzania & 8252 & 1.5 & 96.3 & 1167 & $(584-1751)$ \\
\hline 10 & Saudi Arabia & 4079 & 0.7 & 97.0 & 577 & $(288-865)$ \\
\hline 11 & Myanmar & 3424 & 0.6 & 97.6 & 484 & $(242-726)$ \\
\hline 12 & Malaysia & 3240 & 0.6 & 98.2 & 458 & $(229-687)$ \\
\hline 13 & Mozambique & 3075 & 0.5 & 98.7 & 435 & $(217-652)$ \\
\hline 14 & Bangladesh & 2694 & 0.5 & 99.2 & 381 & $(190-571)$ \\
\hline 15 & Qatar & 2187 & 0.4 & 99.6 & 309 & $(155-464)$ \\
\hline 16 & Comoros & 608 & 0.1 & 99.7 & 86 & $(43-129)$ \\
\hline 17 & Kenya & 543 & 0.1 & 99.8 & 77 & $(38-115)$ \\
\hline 18 & Djibouti & 425 & 0.1 & 99.9 & 60 & $(30-90)$ \\
\hline 19 & Thailand & 298 & 0.1 & 99.9 & 42 & $(21-63)$ \\
\hline 20 & Eritrea & 219 & 0.0 & 100.0 & 31 & $(15-46)$ \\
\hline 21 & Kuwait & 171 & 0.0 & 100.0 & 24 & $(12-36)$ \\
\hline 22 & Bahrain & 19 & 0.0 & 100.0 & 3 & $(1-4)$ \\
\hline 23 & East Timor & 3 & 0.0 & 100.0 & 0 & $(0-1)$ \\
\hline \multirow[t]{2}{*}{24} & Australia & 1 & 0.0 & 100.0 & 0 & $(0-0)$ \\
\hline & Total & 565668 & 100.0 & & 80000 & $(40000-120000)$ \\
\hline
\end{tabular}

and 1990s. In contrast, the Indian Ocean tuna gillnet fishery has been effectively unmanaged; it may be the largest unresolved contemporary cetacean conservation and management issue.

\subsection{Other Indian Ocean tuna fisheries}

The estimates of cetacean bycatch presented here apply only to the Indian Ocean tuna gillnet fisheries. They do not include Indian Ocean cetacean bycatch in other (non-tuna) gillnet fisheries or in other tuna fisheries.

The tuna purse seine fishery accounted for an average of $26 \%$ of reported Indian Ocean tuna catches during 2012-2016 (IOTC 2019). This fishery is dominated by French and Spanish vessels, although several other countries have smaller numbers of purse seiners operating in the region. It is believed that cetacean bycatch is currently very low. The intentional setting on cetaceans was banned by European Union regulation in 2007 and by IOTC resolution in 2013, while EU purse seiners have had 100\% observer coverage since 2015. Regarding the extent of earlier cetacean interactions with this fishery, there is a divergence of opinion. On the one hand, since the purse seine fishery started in the western Indian Ocean in the early 1980s, purse seine fishermen insisted that tuna and dolphins rarely associated in this region, and that there was no dolphin bycatch. These 2 assertions have recently been supported by a study of skippers' logbooks and observer data, which showed that reported dolphin bycatch was indeed close to zero (Escalle et al. 2015). Tuna were reported to associate with whales (species unknown, but likely Bryde's whales Balaenoptera brydei), and sets were made in association with whales, but whale mortality was also reported to be zero (Escalle et al. 2015). On the other hand, it has been suspected for some time (Cockcroft \& Krohn 1994) and is now known that dolphins (particularly spotted dolphins Stenella attenuata) and tunas do associate widely in the western Indian Ocean (Anderson 2014). Purse seine fishermen's reports to the contrary were incorrect; their assertion that there was no small cetacean bycatch is therefore open to re-examination. For whale-associated sets, whale mortality is not zero (Romanov 2002) and may have been in the order of tens per year 
(Anderson 2014). In addition, there were some instances of cetaceans becoming entangled in netting under fish aggregating devices (FADs) deployed by purse seiners (Chanrachkij \& Loog-on 2003, Rajruchithong et al. 2005), although non-entangling FADs are now being adopted throughout the fleet. In short, the scale of historical cetacean bycatch by Indian Ocean purse seine fisheries (which is of interest for population modelling) remains uncertain, although it was presumably much less than that in the gillnet fisheries for most species.

Tuna longline fisheries accounted for an average of $12 \%$ of reported Indian Ocean tuna catches during 2012-2016. Some cetaceans may occasionally become accidentally entangled in longlines, but a more serious issue is that of depredation - the removal or damage of fish or bait from fishing gear by predators (e.g. toothed whales). Depredation is distinct from predation, which refers to the capture of free-ranging fish, and although a widespread phenomenon, it is a particular issue for longline fisheries. Not only do some cetaceans become hooked while taking tuna or bait from longlines, but they are also sometimes deliberately killed by fishermen (Ramos-Cartelle \& Mejuto 2008, Rabearisoa et al. 2009). The species most frequently responsible for depredation from tuna longlines appears to be the false killer whale Pseudorca crassidens (e.g. Anon 2007, Rabearisoa et al. 2012, Anderson 2014). The scale of this source of cetacean mortality in the Indian Ocean is unknown, although Garcia \& Herrera (2018) suggested that longlines accounted for just $0.2 \%$ of marine mammal mortality by Indian Ocean tuna fisheries (with gillnets accounting for almost all of the rest).

In addition to purse seine fisheries and longline fisheries, Indian Ocean cetaceans are also taken accidentally in other tuna and ring-net fisheries (e.g. Prajith et al. 2014) and deliberately by harpoon from a variety of tuna fishing vessels both for human consumption and bait (e.g. Altherr \& Hodgins 2018, Mintzer et al. 2018). Total cetacean bycatch in all Indian Ocean tuna fisheries will therefore be greater than estimated here for just tuna gillnet fisheries. Cetaceans are also taken as bycatch in other nontuna fisheries, for example bottom-set gillnets deployed for demersal species.

\subsection{Cetacean population status}

The tuna stocks against which our cetacean bycatch estimates were scaled are themselves heavily exploited. Because of the differences in life history strategies between tunas and cetaceans (relatively ' $r$ selected' versus relatively ' $K$-selected'), it is to be expected that cetacean population abundance will decline more rapidly than tuna abundance, even though both are harvested by the same fisheries. In recent years, tuna gillnet catches have continued to rise (Fig. S1), reflecting increasing gillnet fishing effort (Aranda 2017). In contrast, estimated cetacean gillnet bycatch appears to have stagnated since the early 1990s and declined in more recent years (Fig. 2), despite the apparent increase in fishing effort. This suggests that in the Indian Ocean, not only is the population status of cetaceans on average worse than that of tunas, but also that fisheries mortality may be unsustainable for at least some cetacean species or populations.

A recent assessment by the IOTC (IOTC 2017a) suggested that all of the tuna and tuna-like species taken by gillnet fisheries are heavily exploited, with the size of most stocks reduced by more than $50 \%$ from their 1950 or virgin biomass (Table S2). The unweighted mean of the stock status indicators in Table S2 is 0.44 , i.e. on average the populations of those tuna species have been reduced to $44 \%$ of their original size. For the same data, the weighted average is 0.40 .

The current cetacean bycatch rate may be in the order of 175 cetaceans per $1000 \mathrm{t}$ of tuna (Table 1, Fig. 1), down from an estimate of 600 prior to 1980. If tuna abundance is currently in the order of $44 \%$ of pre-exploitation levels, then mean cetacean abundance may now be about $13 \%$ of pre-fishery levels $(175 / 600 \times 0.44)$. Using less conservative but still plausible values suggests even lower values of cetacean relative abundance (e.g. $125 / 700 \times 0.40=$ $7 \%)$.

These relative abundance estimates are compatible with abundance estimates for Risso's dolphin off Sri Lanka: both bycatch data and sightings records (Anderson 2013, 2014, Anderson \& Alagiyawadu 2019) suggest that this species may have declined to $10 \%$ or less of its original abundance in Sri Lankan waters, mainly as a result of mortality in gillnet fisheries. Similarly, in the Persian/Arabian Gulf, aerial surveys off UAE suggested that coastal cetacean abundance may have declined to $29 \%$ of 1986 levels by 1999 , with gillnet fishing being a likely contributing factor (Preen 2004). High levels of gillnet bycatch have also been implicated in the local depletion of coastal dolphins in Tanzanian waters (Amir et al. 2005, 2012).

However, these all appear to be examples of local, not ocean-wide, over-exploitation. And our estimates 
of cetacean relative abundance may be biased downwards because of local depletion of cetacean stocks in areas where bycatch sampling was carried out. It seems unlikely that the populations of all cetacean species have been reduced to such low levels across the entire Indian Ocean (including large areas such as the Maldives and the Chagos Archipelago, where gillnetting is banned). This is another area where more detailed analysis, including population modelling, should shed further light. Nevertheless, the suggestion that even some populations of Indian Ocean cetaceans may have been reduced to $13 \%$ or less of pre-exploitation levels should provoke concern from resource managers.

\subsection{Actions and conclusions}

Coastal states do have responsibilities for managing their own fisheries and marine resources, and those with significant gillnet fisheries should start national monitoring and mitigation programs. However, many tunas and cetaceans, and tuna fishing fleets, are highly mobile, often moving between exclusive economic zones (EEZs) and into the high seas, and therefore require international monitoring and management. The 2 inter-governmental organisations with most direct responsibility for these issues are the IOTC and the IWC.

IOTC has responsibility for the monitoring and management of all tuna and tuna-like species in its area of competence, namely FAO Fisheries Areas 51 (the western Indian Ocean south to $45^{\circ} \mathrm{S}$ ) and 57 (the eastern Indian Ocean south to $55^{\circ} \mathrm{S}$ ). IOTC also has responsibility for monitoring and management of species occurring as bycatch in tuna fisheries, including cetaceans, as formalised in its Resolution 13/04 On the Conservation of Cetaceans (IOTC 2013). A UN moratorium on large-scale pelagic driftnet (i.e. length $>2.5 \mathrm{~km}$ ) fishing in the high seas came into effect in 1992, and this is reinforced regionally by an IOTC prohibition, which will be expanded to the entire IOTC area of competence by 2022 (IOTC 2017 b). However, IOTC scored just $18 \%$ in one performance assessment of regional fishery management organisation (RMFO) bycatch governance (Gilman et al. 2014). In a review of small-scale tuna fisheries in the Indian Ocean and southeast Asia, Gillett (2011) noted that many bycatch estimates were no more than 'educated guesses'. A comparative study of ecosystem-based management, which included an assessment on progress with management of marine mammal bycatch (Juan-Jordá et al.
2018), found IOTC to be the worst performing of the tropical tuna RMFOs. Most member countries still fail to monitor and report cetacean bycatch, and the fishermen of several (including Iran, Pakistan and Sri Lanka) continue to fish in the high seas with largescale driftnets. There is a need for compliance.

The IWC did establish an Indian Ocean Sanctuary in 1979. All commercial whaling is banned within this area (which includes the entire ocean south to $\left.55^{\circ} \mathrm{S}\right)$. Beyond that, the IWC has engaged little within the region until very recently.

A key assumption of this study was that the ratio of tuna catchability and cetacean catchability has remained constant over time. A recent trend in the northern Arabian Sea has been towards sub-surface setting of pelagic gillnets (i.e. with the headline several metres below, rather than at, the surface). This can have the effect of reducing cetacean bycatch, with less impact on tuna catch (probably because cetaceans have to spend time at the surface to breathe). From a study off the north coast of Australia, Hembree \& Harwood (1987) found that setting drift gillnets $4.5 \mathrm{~m}$ below the surface resulted in a $50 \%$ reduction in dolphin bycatch, for a $25 \%$ reduction in fish catch. From Sri Lanka, an anecdotal report by Dayaratne \& de Silva (1991) noted that fishermen set their drift gillnets either at the sea surface or below the surface, depending on the current. Fishermen reported that subsurface deployment reduced the bycatch of marine mammals apparently without reducing the catch of target species. More recently, off Pakistan, subsurface setting of gillnets has become popular because it results in higher catches of higher value fish species (notably yellowfin and skipjack tunas). Subsurface setting was introduced in late 2014, and the entire Pakistani fleet had converted before the end of 2016. Setting nets with the headline $2 \mathrm{~m}$ below the surface has been reported to reduce cetacean bycatch by a remarkable $90 \%$, for no change in fish catch (Kiszka et al. 2018). Subsequently some Iranian and Indian vessels started subsurface setting, from 2018 (M. Moazzam unpubl. obs.). This systematic adoption of subsurface setting will presumably have a significant impact on cetacean bycatch, but this in turn may make future application of the methodology used here inappropriate.

Actions that could be taken to start addressing the issue of unsustainable cetacean bycatch in Indian Ocean gillnet tuna fisheries include (1) improving understanding of the existing situation, in particular monitoring of cetacean bycatch in all countries with major gillnet tuna fisheries. Port sampling would be a first step, but since many cetaceans are not landed or 
are landed through unofficial channels (for example because of national conservation laws), on-board monitoring will be required, using both observers and remote technologies. These actions should be complemented by fishery-independent cetacean surveys. (2) Analysing existing and forthcoming information, including review of historical sightings and bycatch data; completion of an ecological risk assessment; modelling of cetacean bycatch and population trends; and estimation of management reference points. (3) Improving fishery governance, including compliance with existing bans on large-scale gillnetting in the high seas; and introduction of a cap on gillnet fishing effort. (4) Making changes in the fishery, in collaboration with fishers, to reduce cetacean bycatch, for example with trials of deep-setting, of acoustically enhanced fibres and of pingers; and investing in alternatives to gillnetting, including alternative (non-fishing) livelihoods and conversion to other fishing methods (with smaller ecological footprints).

Finally, we stress again that the cetacean bycatch estimates presented here are not definitive. They are based on limited bycatch sampling and several assumptions, so are subject to much uncertainty. Nevertheless, they do highlight the potential impact of Indian Ocean tuna gillnet fisheries on regional cetacean populations, and the need for much improved monitoring, mitigation and management.

Acknowledgements. R.C.A. is grateful for financial support for publication from the International Seafood Sustainability Foundation (ISSF). This study builds on an earlier review supported by the International Pole and Line Foundation (IPNLF). We thank Evgeny Romanov, Mohamed Shiham Adam, Omar Amir, Hamed Moshiri and 2 anonymous referees for constructive reviews of drafts of the manuscript.

\section{LITERATURE CITED}

Alling A (1983) A preliminary report of marine mammal fisheries in Djibouti, Oman and Sri Lanka. Document presented at the Symposium on Marine Mammals of the Indian Ocean, Colombo, Sri Lanka, February 1983. NARA/SMMIO/SP32

Alling A (1985) Small cetacean entanglement: a case study of the incidental entrapment of cetaceans in Sri Lanka's gillnet fishery. Paper No. SC/37/SM5 presented to the International Whaling Commission Scientific Committee, 15-19 July 1985, Bournemouth

Altherr S, Hodgins N (2018) Small cetaceans, big problems: a global review of the impacts of hunting on small whales, dolphins and porpoises. Pro Wildlife, Animal Welfare Institute, Whale and Dolphin Conservation. https://whales.org/wp-content/uploads/2018/08/smallcetaceans-big-problems.pdf (accessed 8 Feb 2019)

Amandè MJ, Chassot E, Chavance $\mathrm{P}$, Murua $\mathrm{H}$, de Molina AD, Bez N (2012) Precision in bycatch estimates: the case of tuna purse-seine fisheries in the Indian Ocean. ICES J Mar Sci 69:1501-1510

Amir OA, Berggren P, Jiddawi NS (2002) The incidental catch of dolphins in gillnet fisheries in Zanzibar, Tanzania. West Indian Ocean J Mar Sci 1:155-162

Amir OA, Jiddawi NS, Berggren P (2005) The occurrence and distribution of dolphins in Zanzibar, Tanzania, with comments on the differences between two species of Tursiops. West Indian Ocean J Mar Sci 4:85-93

Amir OA, Berggren P, Jiddawi NS (2012) Recent records of marine mammals in Tanzanian waters. J Cetacean Res Manag 12:249-253

Anderson RC (2013) Risso's dolphin (Grampus griseus): impact of the Sri Lankan gillnet fishery. IOTC-2013WPEB09-30. Indian Ocean Tuna Commission, Victoria

Anderson RC (2014) Cetaceans and tuna fisheries in the western and central Indian Ocean. IPNLF Tech Rep 2. International Pole and Line Foundation, London

Anderson RC, Alagiyawadu A (2019) Observations of cetaceans off southern Sri Lanka in April, 2007-2013. J Cetacean Res Manag 20:13-25

Anon (2007) Report: workshop on the depredation in the tuna longline fisheries in the Indian Ocean, 9-10 July 2007. Indian Ocean Tuna Commission, Victoria. Report no. IOTC-2007-DeWS01-R

Anon (2018) I.R. Iran National Report for the 21nd [sic] scientific committee of the IOTC, 2018. Report no. IOTC2018-SC21-NR10. Indian Ocean Tuna Commission, Victoria

Aranda M (2017) Description of tuna gillnet capacity and bycatch in the IOTC convention area. Report no. IOTC-2017-WPEB13-18. Indian Ocean Tuna Commission, Victoria

Ardill D, Itano D, Gillett R (2012) A review of bycatch and discard issues in Indian Ocean tuna fisheries. Report no. IOTC-2012-WPEB08-INF20. Indian Ocean CommissionSmartFish Programme, Quatres Bornes

Branch TA, Stafford KM, Palacios DM, Allison C and others (2007) Past and present distribution, densities and movements of blue whales Balaenoptera musculus in the Southern Hemisphere and northern Indian Ocean. Mammal Rev 37:116-175

Braulik GT, Ranjbar S, Owfi F, Aminrad T, Dakhteh $\mathrm{SMH}$, Kamrani E, Mohsenizadeh F (2009) Marine mammal records from Iran. J Cetacean Res Manag 11: 49-63

Braulik G, Savadkouhi OS, Fadakar S, Mohammadi H and others (2010) A retrospective investigation of two dolphin mass mortality events in Iran, autumn 2007: (Mammalia: Cetacea). Zool Middle East 49:13-26

Carruthers T (2018) A multispecies catch-ratio estimator of relative stock depletion. Fish Res 197:25-33

Chanrachkij I, Loog-on A (2003) Preliminary report on the ghost fishing phenomena by drifting FADs in eastern Indian Ocean. TD/RES/78. Southeast Asian Fisheries Development Center, Bangkok

Cockcroft VG, Krohn R (1994) Passive gear fisheries of the southwestern Indian and southeastern Atlantic Oceans: an assessment of their possible impact on cetaceans. Rep Int Whaling Comm Spec Issue 15:317-328

Dayaratne P, de Silva J (1991) Drift gillnet fishery in Sri Lanka. IPTP Col Vol Work Docs 4:230-234

Dayaratne P, Joseph L (1993) A study on dolphin catches in Shri Lanka. BOBP/REP/56. Bay of Bengal Programme for Fisheries Development, Madras 
Escalle L, Capietto A, Chavance P, Dubroca L and others (2015) Cetaceans and tuna purse seine fisheries in the Atlantic and Indian Oceans: interactions but few mortalities. Mar Ecol Prog Ser 522:255-268

Fiorellato F, Geehan J, Pierre L (2018) Report on IOTC data collection and statistics. Report no. IOTC-2018-WPDCS 14-07. Indian Ocean Tuna Commission, Victoria

Garcia A, Herrera M (2018) Assessing the contribution of purse seine fisheries to overall levels of bycatch in the Indian Ocean. IOTC-2018-WPDCS14-26. Indian Ocean Tuna Commission, Victoria

Gerrodette T (2009) The tuna-dolphin issue. In: Perrin WF, Würsig B, Thewissen JGM (eds) Encyclopedia of marine mammals, 2nd edn. Academic Press, Burlington, MA, p 1192-1195

Gillett R (2011) Bycatch in small-scale tuna fisheries: a global study. FAO Fish Aquacult Tech Pap No. 560. FAO, Rome

Gilman E, Passfield K, Nakamura K (2014) Performance of regional fisheries management organizations: ecosystem-based governance of bycatch and discards. Fish Fish 15:327-351

Gray HWI, Nishida S, Welch AJ, Moura AE and others (2018) Cryptic lineage differentiation among IndoPacific bottlenose dolphins (Tursiops aduncus) in the northwest Indian Ocean. Mol Phylogenet Evol 122:1-14

Gunaratna R (1989) Brief overview of Sri Lanka's fisheries to 1980. In: Leatherwood S, Reeves RR (eds) Marine mammal research and conservation in Sri Lanka. UNEP, Nairobi, p 10-31

Hall MA (1996) On bycatches. Rev Fish Biol Fish 6:319-352

Hall MA (1998) An ecological view of the tuna-dolphin problem: impacts and trade-offs. Rev Fish Biol Fish 8: $1-34$

Hall M, Roman M (2013) Bycatch and non-tuna catch in the tropical tuna purse seine fisheries of the world. FAO Fish Aquacult Tech Pap No. 568 FAO, Rome

Harwood MB, Hembree D (1987) Incidental catch of small cetaceans in the offshore gillnet fishery in northern Australian waters: 1981-1985. Rep Int Whaling Comm 37: 363-367

Harwood MB, McNamara KJ, Anderson GRV, Walter DG (1984) Incidental catch of small cetaceans in a gillnet fishery in northern Australian waters. Rep Int Whaling Comm 34:555-559

Hembree D, Harwood MB (1987) Pelagic gillnet modification trials in northern Australian seas. Rep Int Whaling Comm 37:369-373

Hewapathirana HPK, Gunawardane NDP (2016) Sri Lanka National Report to the Scientific Committee of the Indian Ocean Tuna Commission. IOTC-2016-SC19-NR27. Indian Ocean Tuna Commission, Victoria

Hewapathirana HPK, Gunawardane NDP, Ariaratne MM (2018) Sri Lanka National Report to the Scientific Committee of the Indian Ocean Tuna Commission, 2018. IOTC-2018-SC21-NR25. Indian Ocean Tuna Commission, Victoria

Hsu CC, Liu HS (1990) Taiwanese longline and gillnet fisheries in the Indian [sic]. Document submitted to the Expert Consultation on Stock Assessment of Tunas in the Indian Ocean, 2-6 July 1990, Bangkok. IPTP Coll Vol Work Docs 4: 244-258. Indian Ocean Tuna Commission, Victoria

Igulu M, El Kharousy Z (2013) Tanzania: National Report to the Scientific Committee of the Indian Ocean Tuna Com- mission, 2013. Report no. IOTC-2013-SC16-NR27. Indian Ocean Tuna Commission, Victoria

Igulu M, El Kharousy ZM (2014) Tanzania: National Report to the Scientific Committee of the Indian Ocean Tuna Commission, 2014. Report no. IOTC-2014-SC17-NR28. Indian Ocean Tuna Commission, Victoria

Ilangakoon AD (1997) Species composition, seasonal variation, sex ratio and body length of small cetaceans caught off west, south-west and south coast of Sri Lanka. J Bombay Nat Hist Soc 94:298-306

Ilangakoon AD (2002) Whales and dolphins of Sri Lanka. WHT Publications, Colombo

Ilangakoon AD (2006) Taxonomy and current status of marine mammals in Sri Lanka. In: Bambaradeniya CNB (ed) The fauna in Sri Lanka: status of taxonomy, research and conservation. IUCN, Colombo, p 302-308

Ilangakoon AD, Miththapala S, Ratnasooriya WD (2000a) Sex ratio and size range of small cetaceans in the fisheries catch on the west coast of Sri Lanka. Vidyodaya J Sci 9:25-35

Ilangakoon AD, Ratnasooriya WD, Miththapala S (2000b) Species diversity, seasonal variation and capture method of small cetaceans on the west coast of Sri Lanka. Vidyodaya J Sci 9:37-52

IOTC (2013) Resolution 13/04 on the conservation of cetaceans. Indian Ocean Tuna Commission, Victoria

IOTC (2017a) Report of the $20^{\text {th }}$ session of the IOTC Scientific Committee. Report no. IOTC-2017-SC20-R. Indian Ocean Tuna Commission, Victoria

IOTC (2017b) Resolution 17/07 on the prohibition to use large-scale driftnets in the IOTC Area. Indian Ocean Tuna Commission, Victoria

IOTC (2019) Indian Ocean Tuna Commission tuna fishery database. www.iotc.org/data-and-statistics (accessed numerous times up until April 2019)

Jayaprakash AA, Nammalwar P, Pillai SK, Elayathu MNK (1995) Incidental by-catch of dolphins at fisheries harbour, Cochin with a note on their conservation and management in India. J Mar Biol Assoc India 37:126-133

* Jefferson TA, Rosenbaum HC (2014) Taxonomic revision of the humpback dolphins (Sousa spp.), and description of a new species from Australia. Mar Mamm Sci 30:1494-1541

Jefferson TA, Waerebeek KV (2002) The taxonomic status of the nominal dolphin species Delphinus tropicalis van Bree, 1971. Mar Mamm Sci 18:787-818

Joseph L, Sideek MSM (1985) Threat to dolphins and small whales from commercial fisheries. Paper presented to the annual meeting of the Sri Lankan Association for the Advancement of Science, Colombo, October 1985

*Juan-Jordá MJ, Murua H, Arrizabalaga H, Dulvy NK, Restrepo V (2018) Report card on ecosystem based fisheries management in tuna regional fisheries management organizations. Fish Fish 19:321-339

Khan WH (2017) Tuna fishery in Pakistan: Pakistan's National Report to the Scientific Committee of the Indian Ocean Tuna Commission, 2017. Report no. IOTC-2017SC20-NR20. Indian Ocean Tuna Commission, Victoria

Khan MF (2018) Tuna fishery in Pakistan: Pakistan's National Report to the Scientific Committee of the Indian Ocean Tuna Commission, 2018. Report no. IOTC-2018SC21-NR20. Indian Ocean Tuna Commission, Victoria

Kiszka J, Muir C, Chris P, Cox TM and others (2008) Marine mammal bycatch in the southwest Indian Ocean: review and need for a comprehensive status assessment. West Indian Ocean J Mar Sci 7:119-136 
Kiszka JJ, Moazzam M, Nivière $M$, Shahid U and others (2018) Cetaceans in the tuna drift gillnet fishery off Pakistan (Arabian Sea): Can we reduce bycatch at low cost with no impact on targeted species catch rates? Report no. IOTC-2018-WPEB14-41. Indian Ocean Tuna Commission, Victoria

Koya KM, Rohit P, Vase VK, Azeez PA (2018) Non-target species interactions in tuna fisheries and its implications in fisheries management: case of large-mesh gillnet fisheries along the north-west coast of India. J Mar Biol Assoc India 60:18-26

Kreb D, Mustika PL, Kahn B, Yanuar A and others (2013) National reviews of status, research, catch, by-catch, conservation and legislation of marine mammals in Indonesia: a country report to the 3rd Southeast Asian Marine Mammal Symposium 2013, Langkawi

Kumarran RP (2012) Cetaceans and cetacean research in India. J Cetacean Res Manag 12:159-172

Lal Mohan RS (1985) Observations of the by-catch of dolphins Stenella longirostris, Tursiops aduncus, Sousa chinensis and Delphinus delphis tropicalis in the gill nets off Calicut coast, India. In: Silas BG (ed) Proc Symp Endangered Species Marine Parks, Vol 1: Marine mammals. Marine Biological Association of India, Cochin, p 78-83

Lal Mohan RS (1994) Review of gillnet fisheries and cetacean bycatches in the northeastern Indian Ocean. Rep Int Whaling Comm Spec Issue 15:329-343

Leatherwood S (1994) Report of the workshop on mortality in passive fishing nets and traps. Annex D. Re-estimation of incidental cetacean catches in Sri Lanka. Rep Int Whaling Comm Spec Issue 15:64-65

Leatherwood S, Reeves RR (eds) (1989) Marine mammal research and conservation in Sri Lanka 1985-1986. UNEP Marine Mammal Tech Rep No. 1. United Nations Environment Programme, Nairobi

Longhurst A (1998) Ecological geography of the sea. Academic Press, San Diego, CA

Macfadyen G (2016) Study of the global estimate of the value of tuna fisheries-phase 3 report. Poseidon Aquatic Resource Management, Lymington

Maunder MN, Hoyle SD (2007) A novel method to estimate relative abundance from purse-seine catch-per-set data using known abundance of another species. Stock Assessment Report No. 7. Inter-American Tropical Tuna Commission, La Jolla, CA, p 283-297

Mendez M, Subramaniam A, Collins T, Minton G and others (2011) Molecular ecology meets remote sensing: environmental drivers to population structure of humpback dolphins in the Western Indian Ocean. Heredity 107: 349-361

Ministry of Marine Affairs and Fisheries (2011) Capture fisheries statistics of Indonesia, 2011, Vol 12, No. 1. Ministry of Marine Affairs and Fisheries, Jakarta

Mintzer VJ, Diniz K, Frazer TK (2018) The use of aquatic mammals for bait in global fisheries. Front Mar Sci 5(191):1-26

Moazzam M (2013) An assessment of cetacean mortality in the gillnet fishery of the northern Arabian Sea. Report no. IOTC-WPEB09-28. Indian Ocean Tuna Commission, Victoria

Moreno G, Herrera M (2013) Estimation of fishing capacity by tuna fishing fleets in the Indian Ocean. Report no. IOTC-2013-SC16-INF04. Indian Ocean Tuna Commission, Victoria
MRAG (2012) A review of bycatch in the Indian Ocean gillnet tuna fleet focussing on India and Sri Lanka. ISSF Tech Rep No. 2012-05. International Seafood Sustainability Foundation, Washington, DC

Mustika PL, Purnomo FS, Northridge S (2014) A pilot study to identify the extent of small cetacean bycatch in Indonesia using fisher interview and stranding data as proxies: updated report to the International Whaling Commission. Whale Stranding Indonesia and University of St. Andrews

Nawaz R, Moazzam M (2014) An assessment of cetacean mortality in the tuna fisheries of Pakistan. Report no. IOTC-2014-WPEB-10-INF25. Indian Ocean Tuna Commission, Victoria

Northridge SP (1991) Driftnet fisheries and their impacts on non-target species: a worldwide review. FAO Fish Tech Pap 320:1-115

Novianto D, Nugroho AF, Zedta RR (2016) Composition and abundance of pelagic shark caught by drift gillnet in Cilacop Oceanic Fishing Port, Indonesia. IOTC-2016WPEB12-17. Indian Ocean Tuna Commission, Victoria

Perrin W (2009) Common dolphins (Delphinus delphis and D. capensis). In: Perrin WF, Würsig B, Thewissen JGM (eds) Encyclopedia of marine mammals, $2^{\text {nd }}$ edn. Academic Press, Burlington, MA, p 255-259

Perrin WF, Donovan GP, Barlow J (eds) (1994) Gillnets and cetaceans. Rep Int Whaling Comm Spec Issue 15:1-629

* Prajith KK, Das PD, Edwin L (2014) Dolphin wall net (DWN) - an innovative management measure devised by ring seine fishermen of Kerala-India to reducing or eliminating marine mammal-fishery interactions. Ocean Coast Manage 102:1-6

* Preen A (2004) Distribution, abundance and conservation status of dugongs and dolphins in the southern and western Arabian Gulf. Biol Conserv 118:205-218

Prematunga WP, Alling A, Leatherwood S (1985) Species composition of small cetacean bycatches in gillnets off Trincomalee, Sri Lanka, January 1984 through April 1985. Paper No. SC/37/SM9 presented to the International Whaling Commission Scientific Committee, 15-19 July 1985, Bournemouth

* Punt AE, Smith DC, Smith AD (2011) Among-stock comparisons for improving stock assessments of data-poor stocks: the 'Robin Hood' approach. ICES J Mar Sci 68:972-981

Rabearisoa N, Bach P, Lucas V, Giroux F and others (2009) Assessment of the efficiency of the physical protection of fish as mitigation measure to depredation by marine mammals in pelagic longlining. Report no. IOTC-2009WPEB-12. Indian Ocean Tuna Commission, Victoria

* Rabearisoa N, Bach P, Tixier P, Guinet C (2012) Pelagic longline fishing trials to shape a mitigation device of the depredation by toothed whales. J Exp Mar Biol Ecol 432433:55-63

Radhalekshmy SK, Nayar SG (1973) Synthetic fibres for fishing gear. Fish Technol 10:142-165

Rajruchithong S, Prajakjitt P, Siriraksophon S (2005) Bycatch from tuna purse seine and longline fishing gears in the eastern Indian Ocean by MV SEAFDEC. Report no. IOTC-2005-WPBy-07. Indian Ocean Tuna Commission, Victoria

Ramos-Cartelle A, Mejuto J (2008) Interaction of the false killer whale (Pseudorca crassidens) and depredation on the swordfish catches of the Spanish surface longline fleet in the Atlantic, Indian and Pacific Oceans. Col Vol Sci Pap ICCAT 62:1721-1738 
Reeves R, Crespo E, Gales N (2005) Global priorities for reduction of cetacean bycatch. World Wide Fund for Nature, Washington, DC

Reeves RR, McClellan K, Werner TB (2013) Marine mammal bycatch in gillnet and other entangling net fisheries, 1990 to 2011. Endang Species Res 20:71-97

Robineau D (1991) Balaenopterid sightings in the western tropical Indian Ocean (Seychelles area), 19821986. In: Leatherwood S, Donovan GP (eds) Cetaceans and cetacean research in the Indian Ocean Sanctuary. UNEP Marine Mammal Tech Rep No. 3. United Nations Environment Programme, Nairobi, p 171-178

Rocha RC Jr, Clapham PJ, Ivashchenko YV (2014) Emptying the oceans: a summary of industrial whaling catches in the 20th century. Mar Fish Rev 76(4):37-48

Romanov EV (2002) Bycatch in the tuna purse-seine fishery in the western Indian Ocean. Fish Bull 100: 90-105

Samaran F, Stafford KM, Branch TA, Gedamke J and others (2013) Seasonal and geographic variation of southern blue whale subspecies in the Indian Ocean. PLOS ONE 8:e71561

Sathasiva Lingom T (2002) A study on fishnet industry in Kanniyakumari district. PhD thesis, Manonmaniam Sundaranar University, Tirunelveli

Sathasivam K (2004) Marine mammals of India. Universities Press, Hyderabad

Shahid U, Moazzam Khan M, Nawaz R, Dimmlich W, Kiszka $\mathrm{J}$ (2015) A preliminary assessment of shark bycatch in tuna gillnet fisheries of Pakistan (Arabian Sea). IOTC2015-WPEB11-46_Rev_1. Indian Ocean Tuna Commission, Victoria

Shahid U, Moazzam Khan M, Nawaz R, Razzaq SA, Ayub S (2016) Bycatch analysis of tuna gillnet fisheries of Pakistan: an analysis of bycatch data from 2013-2015. IOTC-

Editorial responsibility: Eric Gilman,

Honolulu, Hawaii, USA
2016-WPEB12-INF11. Indian Ocean Tuna Commission, Victoria

Shahifar R (2012) Estimation of bycatch and discard by Iranian fishing vessels (gillnets) in IOTC area of competence in 2012. IOTC-2012-WPEB08-42. Indian Ocean Tuna Commission, Victoria

Shahifar R (2017) Iranian fishing vessels by-catch in IOTC competence of area in 2016. IOTC-2017-WPEB13-12. Indian Ocean Tuna Commission, Victoria

Spalding MD, Fox HE, Allen GR, Davidson N and others (2007) Marine ecoregions of the world: a bioregionalization of coastal and shelf areas. Bioscience 57:573-583

Spalding MD, Agostini VN, Rice J, Grant SM (2012) Pelagic provinces of the world: a biogeographic classification of the world's surface pelagic waters. Ocean Coast Manage 60:19-30

Stensland E, Berggren P, Johnstone R, Jiddawi N (1998) Marine mammals in Tanzanian waters: urgent need for status assessment. Ambio 27:771-774

* Temple AJ, Kiszka JJ, Stead SM, Wambiji N and others (2018) Marine megafauna interactions with small scale fisheries in the southwestern Indian Ocean: a review of status and challenges for research and management. Rev Fish Biol Fish 28:89-115

*Vert-pre KA, Amoroso RO, Jensen OP, Hilborn R (2013) Frequency and intensity of productivity regime shifts in marine fish stocks. Proc Natl Acad Sci USA 110: 1779-1784

Wade PR, Reeves RR, Mesnick SL (2012) Social and behavioural factors in cetacean responses to overexploitation: Are odontocetes less 'resilient' than mysticetes? J Mar Biol 2012:567276

Yousuf KSSM, Anoop AK, Anoop B, Afsal VV and others (2009) Observations on incidental catch of cetaceans in three landing centres along the Indian coast. Mar Biodivers Rec 2:e64

Submitted: February 25, 2019; Accepted: November 6, 2019 Proofs received from author(s): December 30, 2019 